\title{
Histological Identification of the Interstitial Cells of Cajal in the Guinea-pig Small Intestine*
}

\author{
Shigeru Kobayashi ${ }^{1}$, John B. Furness, Terence K. Smith and Sueli PomPolo ${ }^{2}$ \\ Department of Anatomy ${ }^{1}$, Yamanashi Medical College, Yamanashi, Japan and Department of Anatomy and Histology ${ }^{2}$, Flinders \\ University, Bedford Park, Australia
}

Received February 1, 1989

Summary. In order to clarify the contraversial structure that CAJAL $(1889,1893,1911)$ called "interstitial cells" in the intestine, we have compared the descriptions by CAJAL with our recent findings.

CaJAL defined three groups of interstitial cells in the intestine: those in the mucosa, the deep muscular plexus, and the myenteric plexus. In the deep muscular plexus, he described cells with small perikarya and long, branching processes. Neither glial cells nor ZIO positive fibroblast-like cells, the only cell types seen in the numbers and location necessary to support CAJAL's observations, conformed with the morphology he described. CAJAL might have described a composite cell, or chimera, the cell body being that of a glial (or perhaps a fibroblast-like) cell and the processes being simultaneously stained neurites that ran in close association with the cell.

In the myenteric plexus, staining with $S-100$ protein for glial cells and ZIO for fibroblast-like cells reveal cells between the external muscle layers. Cells stained with S-100 protein resemble the drawings and also his description of the interstitial cells, although these cells appear to be less frequent than CAJAL's drawings indicate. There are numerous glial cells in the ganglia and primary strands of the plexus which were not included in CAJAL's publications. Conversely, the fibroblast-like cells are incidentally associated with nerve fibers. Although they lie in the same plane, the fibroblast-like cells form a pattern distinct from that of the nerve fibers of the tertiary component of the myenteric plexus. These cells occur in the distribution and numbers of the interstitial cells described by CAJAL. They are stained by ZIO and also immunoreactive for gammaaminobutyric acid. They can be identified by scanning electron microscopy.

In the mucosa, Golgi staining reveals a pattern of nerve fiber bundles that is indistinguishable from CAJAL's drawings. Glial cell bodies frequently occur at the intersections of these bundles and appear as cell nuclei surrounded by a cytoplasm which is actually the stained nerve fiber bundles. What CAJAL depicted as interstitial cells were composite structures consisting of glial cells and contiguous nerve fiber bundles.

We conclude that the structures which CAJAL called interstitial cells in the intestine do not originate from one cell type. Nevertheless, two groups of fibroblastlike cells, those lying parallel and close to the nerve strands of the deep muscular plexus and those of the myenteric plexus, can be recognized by ZIO staining and scanning electron microscopy. These should be called interstitial cells in conformity with general usage and the numbering system adopted by ThuneBerg (1982), i. e., ICC-I for those at the level of the myenteric plexus, and ICC-III for those associated with the deep muscular plexus.

Debate has continued to this day over the possible roles of the "interstitial cells of CAJAL" (see review by THUNEBERG, 1982). The discourse has been strongly influenced by CAJAL's own view of these cells being neuron-like and in intimate association with nerve fibers. If the regions where CAJAL described the interstitial cells are carefully examined by light and electron microscopy, nerve cell bodies can be found only rarely, and certainly do not form the rich network described by CAJAL (THUNEBERG, 1982). Within the

\footnotetext{
*The major part of this work was done at Flinders University where Dr. KoBAYASHI was an Australian Vice Chancellor's Committee Visiting Fellow. Dr. S. Pompolo was in receipt of a Fellowship from the Fundação de Ampãro a Pesquisa do Estado de São Paulo, Brasil (grant no. 86/1788-1).

This work was supported by a Grant-in-Aid of Scientific Research (No. 62480093) from the Japanese Ministry of Education, Science and Culture and a grant from the National Health and Medical Research Council of Australia.
} 
intestine in these regions are two types of abundant cells: enteric glial cells (Schwann cells) and fibroblast-like cells. A population of fibroblast-like cells can be stained with the Champy-Maillet zinc iodide/ osmium (ZIO) method now commonly used to reveal the "interstitial cells of Cajal" (STACH, 1972; PelleGRINO DE IRALDI, 1977; RUMESSEN and THUNEBERG, 1982; CHRISTENSEN et al., 1987).

CAJAL published only a smalll number of drawings of interstitial cells in the intestine, although he repeated these or their variants a number of times. We have reproduced the three survey drawings of interstitial cells in the mucosa, deep muscular plexus and at the level of the myenteric plexus that he chose for his book in 1911 (Figs. 1-3). In the mucosa, these cells were drawn as triangular or fusiform with their processes forming the network of nerve fibers of the villi. Modern methods fail to find nerve cells with such a distribution, although the network of nerve fibers revealed is similar to CAJAL's drawing.

CAJAL's drawing of the deep muscular plexus shows interstitial cells of considerable complexity. CAJAL described the cell bodies as small and often lodged in spaces formed in nerve fiber bundles (see Fig. 3). He suggested that the muscle received its principal innervation from the nerve cell bodies of the myenteric plexus and an accessory innervation from the interstitial cells. His drawings and descriptions of these cells are difficult to reconcile with modern observations, because the cells he described do not closely resemble either the ZIO-reactive fibroblast-like cells or the enteric glial cells. In the present work we re-rexamined these two cell types. The lack of correspondence between CAJAL's description and further recent observations have led KobAyAshi et al. (1986) to propose that CAJAL described a chimera in which the cell body of a glial cell and intimately related nerve fibers had been depicted as if they were a single cell. This possibility was previously raised by LAWRENTJEW $(1925,1926)$ and has been cogently discussed by BOTAR (1966).

In the space between the longitudinal and circular components of the muscularis externa, CAJAL described a network of small cells with fine branching processes (Fig. 2). We have compared these both to the fibroblast-like cells and to enteric glial cells.

The idea that CAJAL may have in fact mistakenly seen continuous glial (Schwann) cell and neurite chimeras as single cells is further suggested by the drawings made by his contemporary DoGIEL (1899), apparently the first to call them the cells of Cajal. Drawings that DoGIEL published of the cells of Cajal (sternförmige Zellen) adjacent to vessels in the wall of the intestine (Figs. 4, 5) do not resemble any cell revealed in modern studies; they appear to be composites of the cell bodies of glial cells and some of the varicose nerve fibers that the glial cells envelop.

Thus, a number of possibilities exist. CAJAL may have described fibroblast-like cells as interstitial cells or he may have been observing glial cell-neurite chimeras. Moreover, he could have identified different structures as interstitial cells in different layers of the gut wall.

In the present work we have tried to assess which cell or cells CAJAL observed. We have compared his original drawings and descriptions with cells revealed by ZIO and Golgi staining, by scanning electron microscopy and by immunoreactivity for gammaaminobutyric acid and the glial cell marker, protein S-100.

\section{MATERIALS AND METHODS}

This study used the small intestine from guinea-pigs at weights ranging from 200 to $350 \mathrm{~g}$.

\section{Champy-Maillet zinc iodide-osmium (ZIO) stain- ing}

The osmic acid-potassium iodide stain of CHAMPY (1913) was modified by MAILLET's (1959) introducing zinc iodide (ZI) instead of potassium iodide. The method of zinc iodide/osmium (ZIO) staining used in the present study was that described by TAXI (1965).

The staining solution was a mixture of 3 to 4 parts of zinc iodide and 1 part of a $2 \%$ solution of osmium tetroxide $\left(\mathrm{OsO}_{4}\right)$. In the fume cupboard, $1 \mathrm{~g}$ crystalline iodine was put into $240 \mathrm{ml}$ distilled water in a glass beaker and mixed with $3 \mathrm{~g}$ of powdered zinc. The mixture was agitated for about $2 \mathrm{~min}$, allowed to stand for about $5 \mathrm{~min}$, and then filtered through Whatman No. 5 filter paper. The zinc iodide was prepared fresh for each experiment.

Whole mount preparations of the myenteric plexus and longitudinal muscle, deep muscular plexus layer, submucous layer with deep muscular plexus, and periglandular plexus layers were prepared by dissection under the microscope in phosphate buffered saline. They were mounted on chrome-alum-gelatin coated glass slides by the "slide sandwich method" as previonsly described (see FURNESS et al., 1988).

ZIO stained whole-mount held between glass slides were dehydrated through an ethanol series, removed from the slides, dipped in $100 \%$ ethanol followed by xylene, and embedded in Depex. 

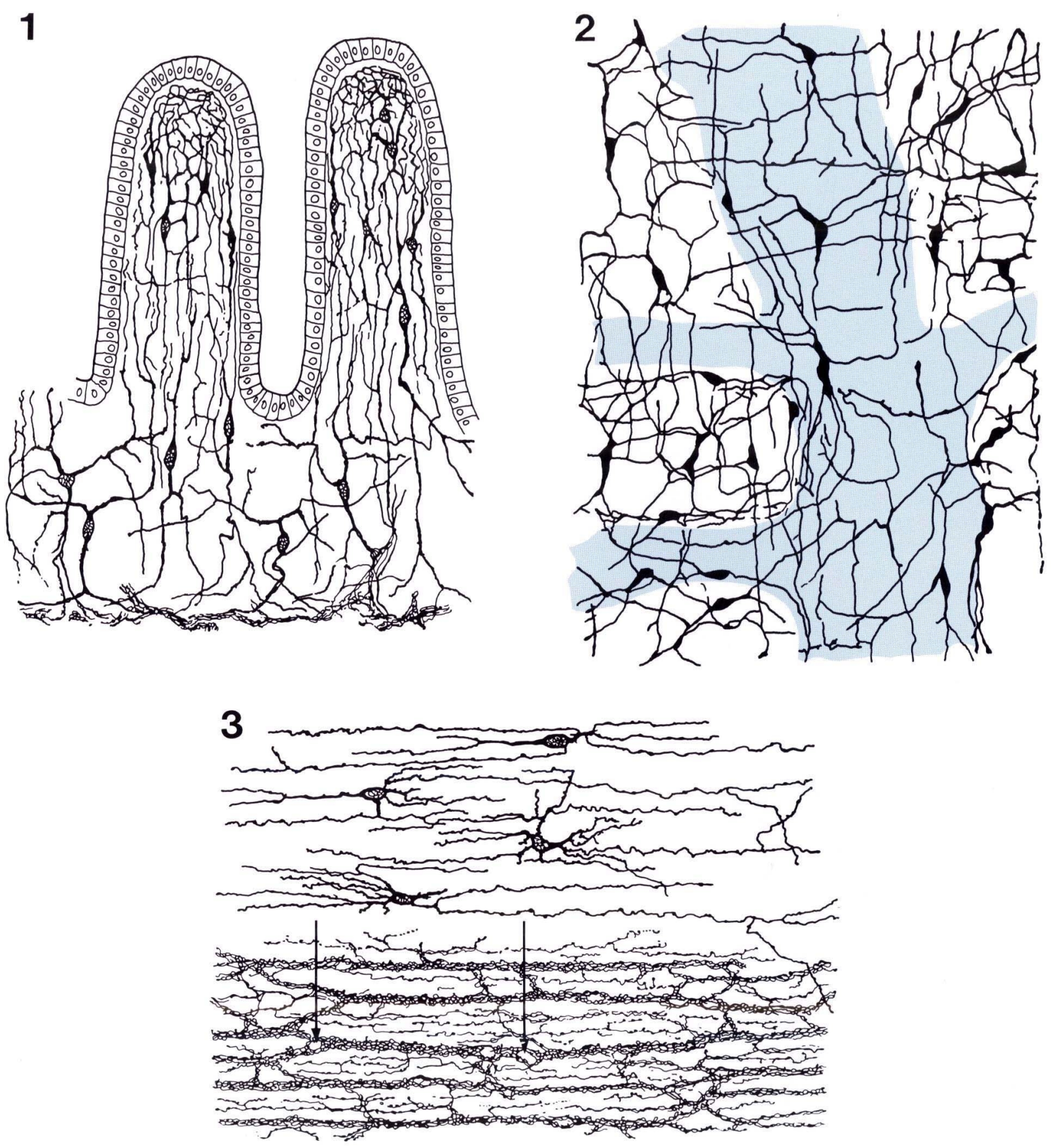

Figs. 1-3. Drawings published by CAJAL of interstitial cells in the mucosa (Fig. 1), in the plane of the myenteric plexus between the longitudinal and circular muscle layers (Fig. 2) and at the level of the deep muscular plexus (Fig. 3). Figs. 1 and 3: the guinea-pig small intestine, Fig. 2: the rabbit small intestine. Fig. 3. Interstitial cells are shown in the upper panel and the nerve fibers that accompany them are in the lower panel. Arrows indicate the holes designated by CAJAL as locations of the cell bodies of interstitial cells. 

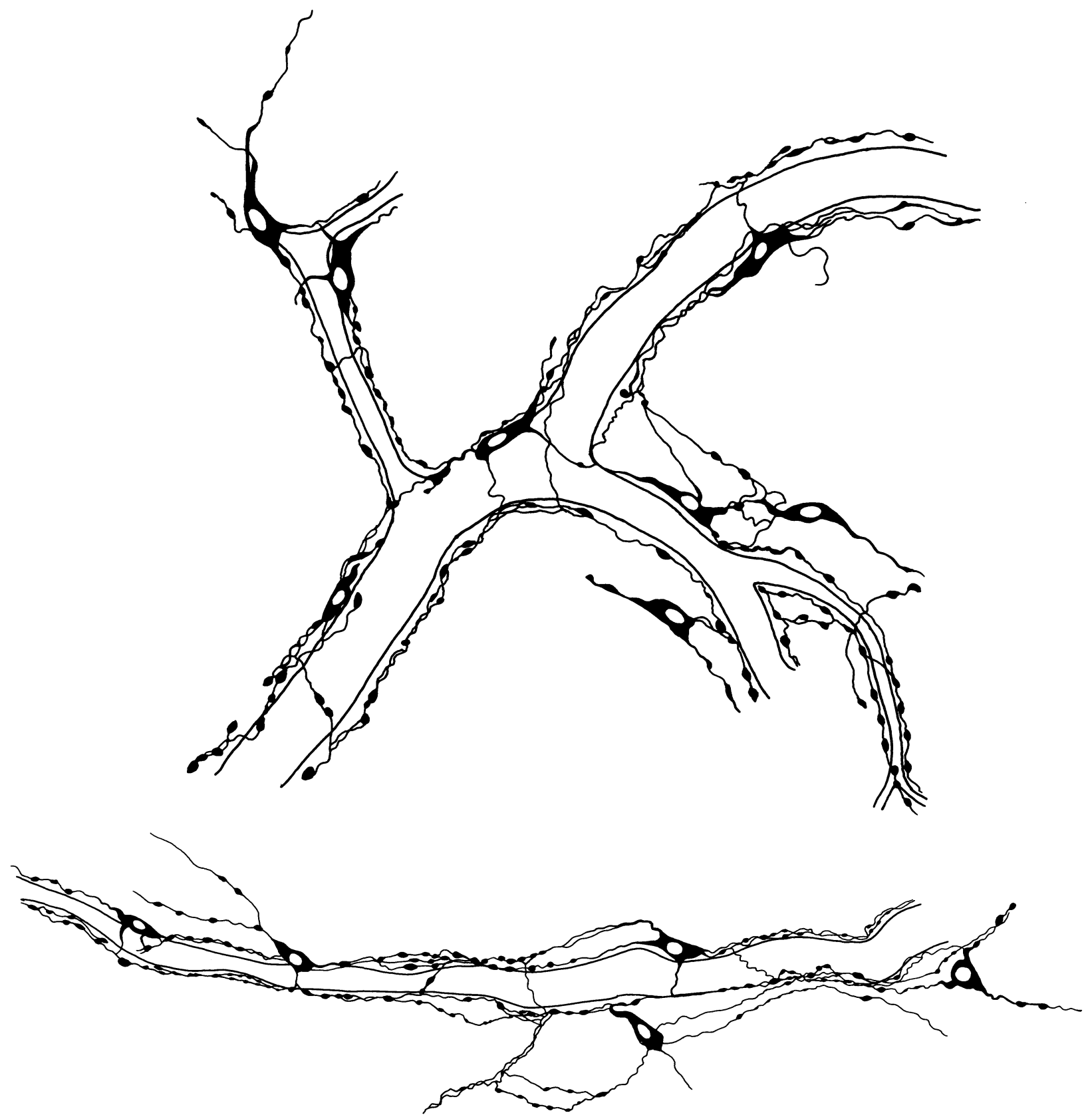

Fig. 4. Drawing by Dogiel (1899) of interstitial cells (sternförmige Zellen) accompanying blood vessels in the small intestine of the guinea-pig. This is based on methylene blue staining. From a comparison with ZIO stained preparations (Fig. 13) and with S-100 immunoreactivity, it is clear that these cells are artefactual chimeras between glial cells and neurites.

Fig. 5. Nerve networks of the villous and periglandular plexuses of the guinea-pig small intestine. A. Photomicrograph of a Golgi silver-impregnated preparation (about $80 \mu \mathrm{m}$ thick) of the mucous coat. B. Corresponding camera lucida drawing. Nerve strands consisting of glial cells and nerve fiber bundles are selectively stained. Almost the entire extent of the three-dimensional nerve network is revealed, although it is impossible to show the whole nerve network in focus in a micrograph. Because of the intensity of the staining, the fiber bundles and the glial cell nuclei appear continuous, thus a false impression of multipolar cells is created (arrows). These are the glial cell-neurite chimeras referred to in the text and previously recognized as artefacts by LAWRENTJEW $(1925,1926)$. $C$ base of the intestinal crypt, $V$ locations of the roots of the intestinal villi. Calibration: $20 \mu \mathrm{m}$. 

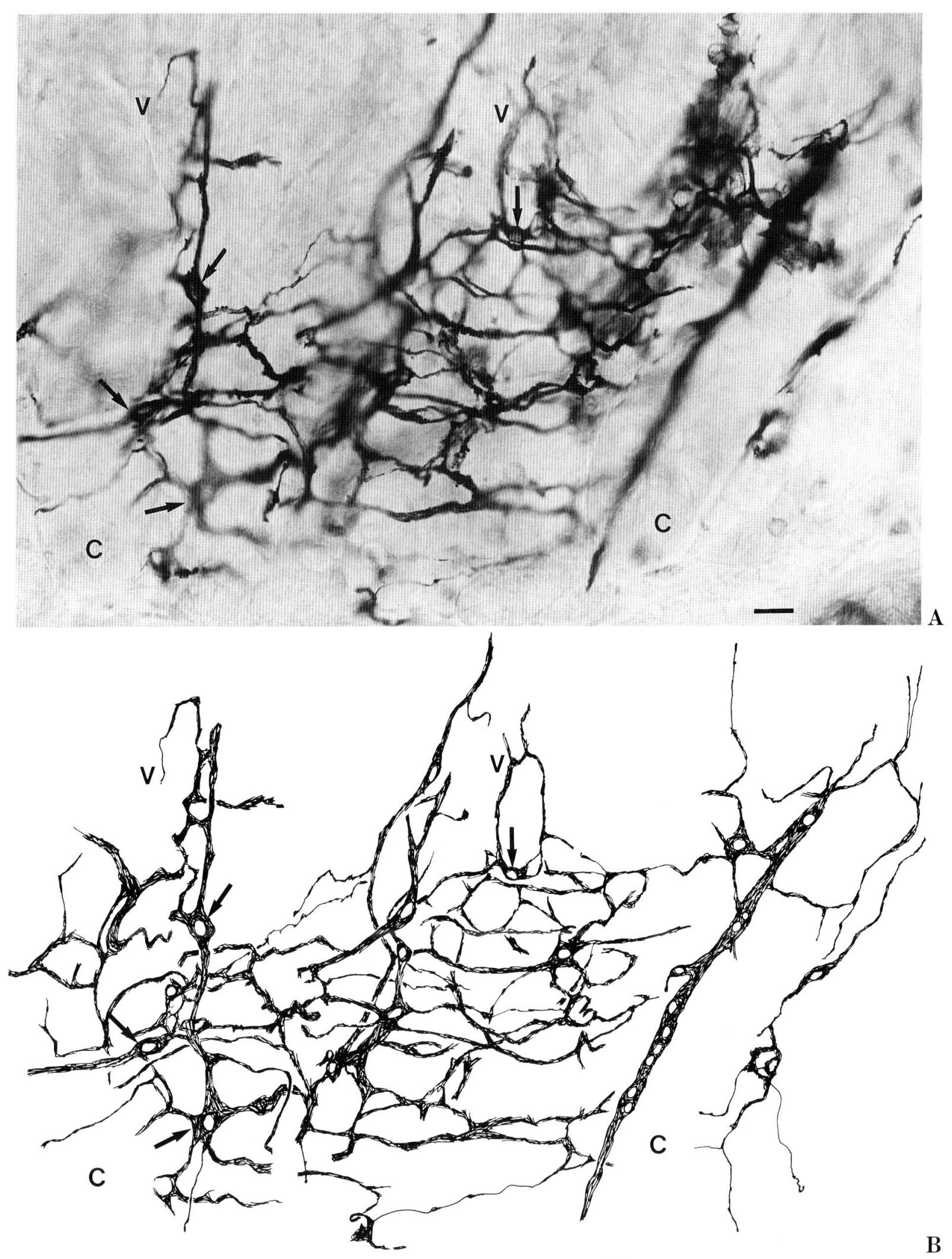

Fig. 5. Legend on the opposite page. 
For the study of the mucosal plexus, especially the periglandular and villous plexuses, separate sections were sometimes used. Pieces of the intestinal mucosa, block-stained in the ZIO solution for 12-24 h, were washed in several changes of distilled water, dehydrated through an ethanol series, treated with xylene and embedded in paraffin. Sections (12-16 $\mu \mathrm{m}$ thick) were cut on a microtome, deparaffinized with xylene and mounted in Depex.

The following modifications of the ZIO-staining method were made: 1 ) the addition of a small mount of Tris- $\mathrm{HCl}$ buffer; 2) an increase in the relative osmium concentration in the ZIO solution; and 3) extended treatment in $\mathrm{ZIO}$ solution.

\section{Rapid Golgi silver impregnation}

A rapid Golgi method (see CAJAL, 1911; MANNEN, 1988) was used in the present study. Pieces of the small intestine were imersed for 1-10 days in a 3:1 mixture of $3 \%$ potassium dichromate and $2 \%$ osmium tetroxide at room temperature. They were rinsed briefly in several changes of $0.75 \%$ silver nitrate in distilled water, stored about $24 \mathrm{~h}$ in a fresh volume of this $0.75 \%$ silver nitrate solution, quickly dehydrated through an ethanol series, and embedded in celloidin. Sections were cut at 50-100 $\mu \mathrm{m}$, mounted on glass slides and examined by light microscopy.

\section{Immunohistochemistry of enteric glial cells}

Enteric glial cells were localized in whole mounts that had been prepared from tissues fixed in a buffered mixture of picric acid and formaldehyde (Zamboni's fixative). The fixative was removed with dimethylsulphoxide, and the tissue processed for immunohistochemistry in whole mounts as previously described (FURNESS et al., 1987). The primary antiserum was raised against the glial cell marker, S100b protein (KOBAYASHI et al., 1986).

\section{Immunohistochemistry for GABA}

Segments of guinea-pig small intestine were washed in a culture medium (medium DME-F12; Sigma Chemical Corp., St. Louis, Mo). The medium was kept at $37^{\circ} \mathrm{C}$ and bubbled with medical air containing $5 \% \mathrm{CO}_{2}$. To this medium was added: nicardipine $(3 \times$ $\left.10^{-5} \mathrm{M}\right)$, to prevent muscle contraction; aminooxyacetic acid $\left(2 \times 10^{-5} \mathrm{M}\right)$, to block GABA-transaminase activity; and $\beta$-alanine $\left(10^{-3} \mathrm{M}\right)$, to prevent GABA uptake into glial cells. Segments were pinned without stretching, the muscle side uppermost, to Sylgard in a
Petri dish. The preparation was maintained in this aerated medium at $37^{\circ} \mathrm{C}$ for a further $20 \mathrm{~min}$, following which GABA $\left(5 \times 10^{-9} \mathrm{M}\right)$ was added and the incubation continued for $60 \mathrm{~min}$ longer. The preparations were then re-pinned and stretched on balsa wood frames so at to expose both surfaces and then placed in a fixative at room temperature for $3.5 \mathrm{~h}$. The fixative was $2 \%$ formaldehyde, $0.05 \%$ glutaraldehyde and $15 \%$ of a saturated aqueous solution of picric acid in sodium phosphate buffer, $\mathrm{pH}$ 7.0. The specimens were then unpinned and washed in three $10 \mathrm{~min}$ changes of dimethylsulphoxide, followed by three 10 min changes of phosphate buffered saline (PBS; $0.9 \%$ $\mathrm{NaCl}$ in $0.01 \mathrm{M}$ sodium phosphate buffer, $\mathrm{pH}$ 7.0). The preparations were then agitated in $0.1 \% \mathrm{NaCNBH}_{3}$ in $0.1 \mathrm{M}$ sodium phosphate buffer for $30 \mathrm{~min}$ and washed in three PBS changes of 15 min each with four subsequent $1 \mathrm{~h}$ changes, with agitation, in PBS. The tissue was transferred to PBS containing 0.1\% $\mathrm{NaCN}$. The intestine that was not loaded with GABA was also fixed and processed for GABA localization.

The gut wall was dissected into layers and developed for the immunohistochemical localization of GABA using antiserum RIOA (MALEY and NEWTON, 1985) at a dilution of 1:200. Absorption controls were made using protocols by OTTERSEN et al. (1986) (see FURNESS et al., 1989). The reaction was developed using an avidin-biotin-HRP method (FURNESS et al., 1988).

\section{Myectomy operations}

Guinea-pigs were anaesthetized with a mixture of pentobarbital $(15 \mathrm{mg} / \mathrm{kg})$, fentanyl $(0.2 \mathrm{mg} / \mathrm{kg})$ and droperidol $(10 \mathrm{mg} / \mathrm{kg})$. A segment of intestine was exteriorized through a mid-line incision and the external muscle was removed from a full circumference of $4-8 \mathrm{~mm}$ of intestine (FURNESS and CosTA, 1979). The guinea-pigs were allowed 4-6 days recovery and then taken for histological examination.

\section{Scanning electron microscopy}

The $\mathrm{NaOH}$ maceration method invented by TAKAHASHI-IWANAGA and FujiTA (1986) for the observation of Ito cells in the rat liver was used with minor modifications.

Guinea-pigs were anaesthetized with sodium pentobarbital and perfused through the thoracic aorta with Ringer's solution followed by $2.5 \%$ glutaraldehyde in $0.1 \mathrm{M}$ sodium phosphate buffer, $\mathrm{pH}$ 7.2. Pieces of the small intestine were excised and immersed in the same fixative for at least one week, and 
rinsed in distilled water. To examine the inner (submucosal) surface of the DMP layer, the submucous coat was removed with watchmaker's forceps. The inner surface of the circular muscle layer was manipulated to form a convex surface under the dissection microscope. The specimen retained this convex shape during the following procedures. For examination of layers other than the DMP, establishing the convex surface was not necessary.

The tissue pieces were placed in a concentrated $\mathrm{NaOH}$ solution (7.2 $\mathrm{g} \mathrm{NaOH}$ in $30 \mathrm{ml}$ distilled water) for $14-16$ min at $60^{\circ} \mathrm{C}$. After the $\mathrm{NaOH}$ maceration, the tissue pieces were rinsed in a diluted $(10 \%)$ Ringer's solution for $10 \mathrm{~min}$ at $60^{\circ} \mathrm{C}$. After several changes of diluted Ringer's solution, the tissue pieces were carefully dipped in a solution containing $2 \%$ arginine chloride, $2 \%$ glycine, $2 \%$ sodium glutamate and $2 \%$ sucrose, rinsed in distilled water and immersed for 2 to $14 \mathrm{~h}$ in $2 \%$ tannic acid in distilled water
(Murakami, 1974). They were then stained for 2-12 h in $1 \% \mathrm{OsO}_{4}$ solution, washed thoroughly in distilled water, dehydrated through an ethanol series, transferred to isoamyl acetate and critical-point dried using liquid $\mathrm{CO}_{2}$ (TAKAhashi-IWANAGA and Fujita, 1986). After critical-point drying, the intestinal tissues were carefully dissected under a microscope using watchmaker's forceps.

For examination of the myenteric plexus, we placed a piece of double-sided adhesive tape on a stage. The intestinal tissue was pressed on to the tape with the concave serosal surface facing down. Tissue layers were then peeled away leaving the longitudinal muscle layer with the myenteric plexus adhering to the tape.

The specimens were evaporation-coated in an Eiko 1B-3 ion coater with gold-palladium and examined and photographed in a JSM T220 scanning electron microscope at an acceleration voltage of 10 or $15 \mathrm{kV}$.
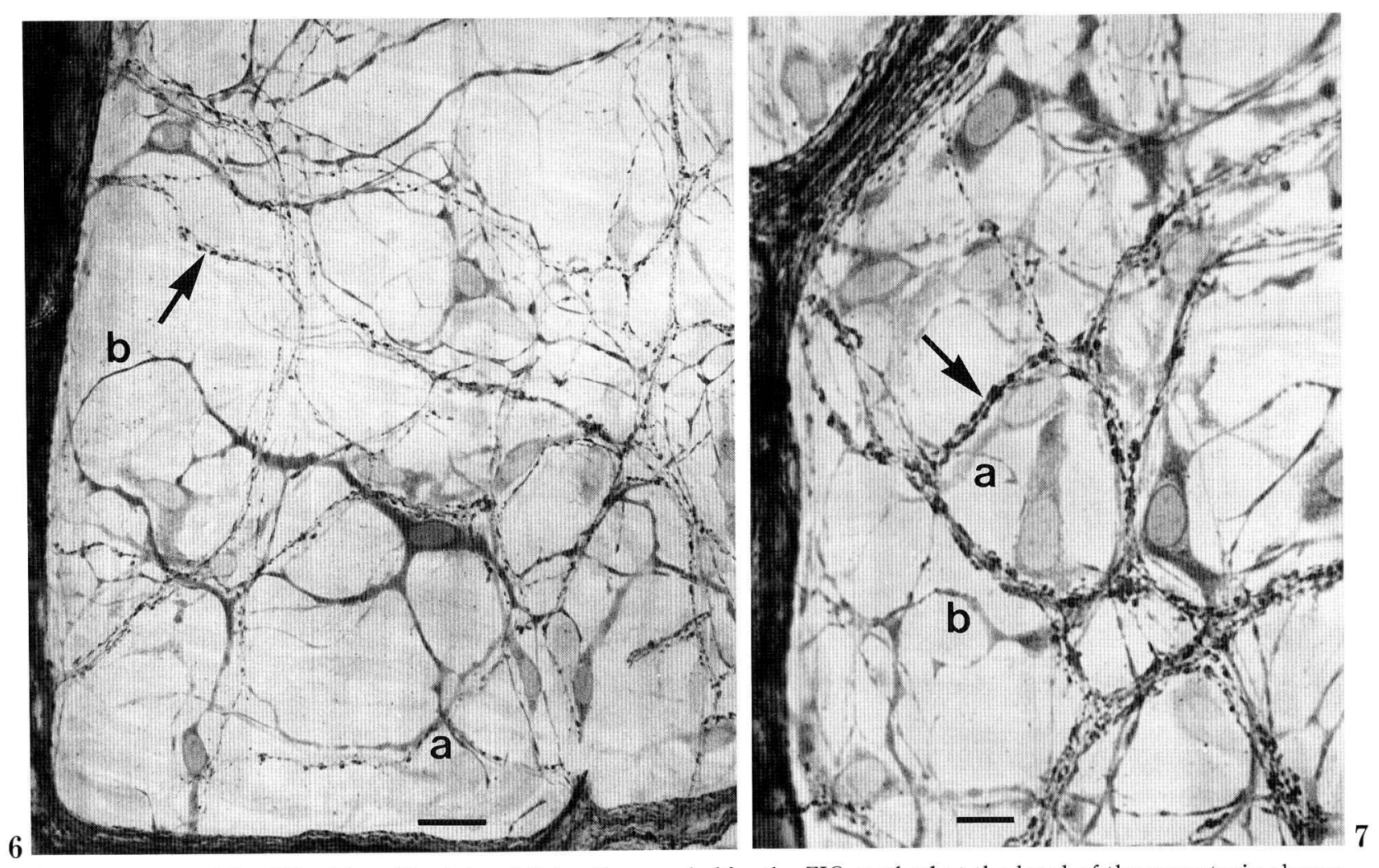

Figs. 6 and 7. Fibroblast-like interstitial cells revealed by the ZIO method at the level of the myenteric plexus, between the external longitudinal and circular muscle layers. Nerve fibers of the tertiary component of the myenteric plexus are also stained (arrows). The fibroblast-like cells often have elaborate processes that sometimes come close to nerve fiber bundles $(a)$, but are in other cases remote from the bundles $(b)$. Calibrations: $20 \mu \mathrm{m}$. 


\section{RESULTS}

\section{Variation of ZIO staining method}

With the conventional ZIO method, there was intense staining of nerve fibers and weak staining of other elements, notably fibroblast-like cells. The addition of a few drops of Tris- $\mathrm{HCl}$ buffer $(0.1 \mathrm{M}, \mathrm{pH}$ 7.6) to $10 \mathrm{ml}$ of the ZIO mixture greatly changed the cellular elements stained by the ZIO method: the staining of the non-neuronal elements was enhanced, whereas that of neuronal elements was suppressed.

An increase in the relative osmium concentration of the ZIO solution augmented the number of visible non-neuronal cells. Although we did not perform systematic experiments, it was obvious that $\mathrm{ZIO}$ positive non-neuronal cells are more numerous in those preparations stained in the solution containing 1 part $\mathrm{OsO}_{4}$ and 3 part $\mathrm{ZI}$ than those in the preparation treated in the solution containing 1 part of $\mathrm{OsO}_{4}$ and 4 part ZI. Most of the ZIO positive non-neuronal cells were fibroblasts or fibroblast-like cells. Smooth muscle cells and vascular endothelial cells were weakly stained by the ZIO method. Basal-granulated cells of the mucosal epithelium were consistently stained.

Treatment of the specimen for a long time (24, 36 h) increased the contrast of the fibroblast-like cells, thus facilitating their visualization. However, extended staining resulted in a heavy background deposition of stain. This excess staining hindered the discrimination of individual neuronal processes.
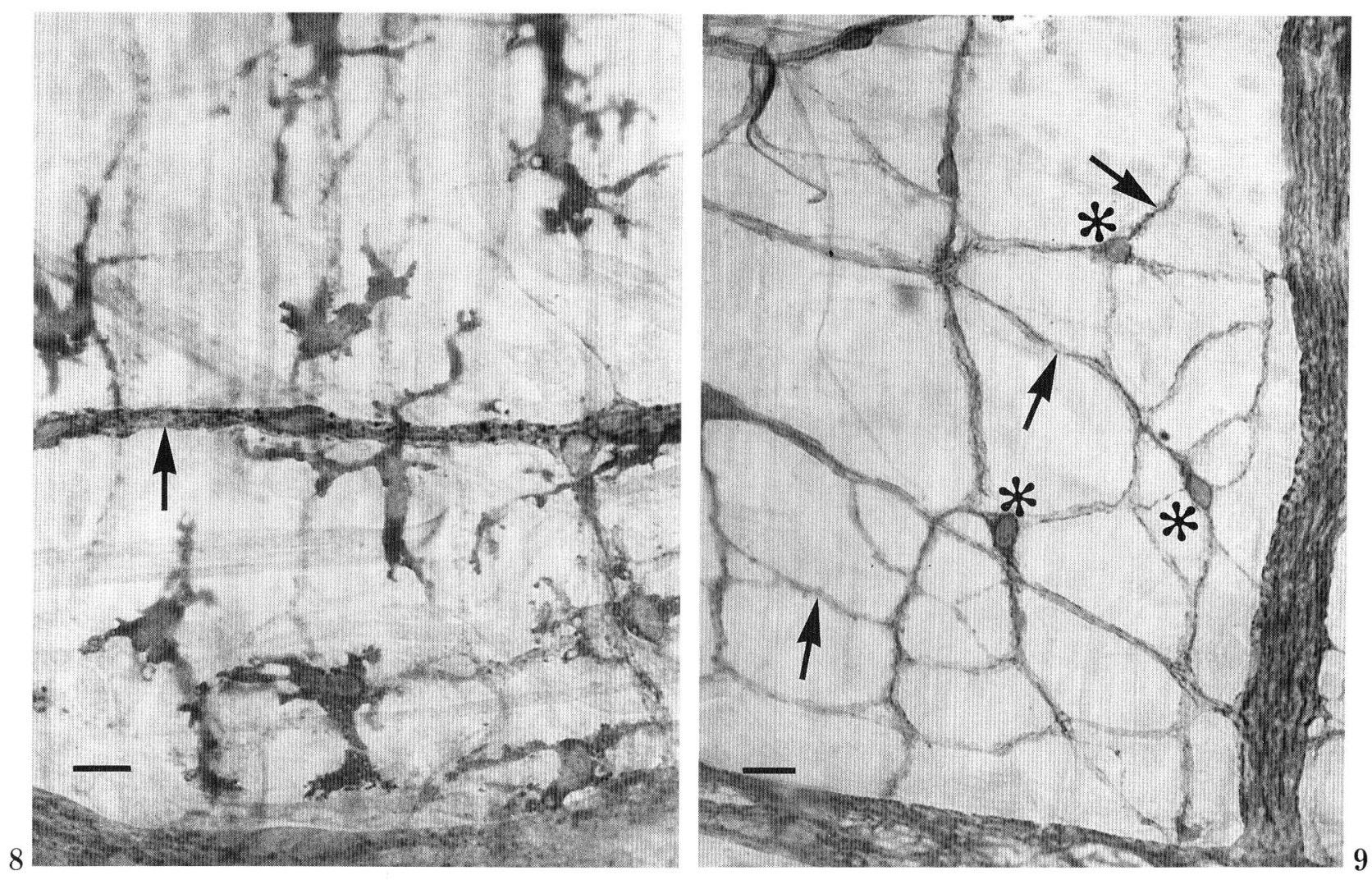

Figs. 8 and 9. Comparison of the pattern of staining seen with anti-GABA antiserum (Fig. 8) and with antiserum to the glial cell marker protein, S-100 (Fig. 9). Fig. 8. Anti-GABA stains a population of fibroblast-like cells whose shapes, sizes and distribution suggest that they are identical with the fibroblast-like cells with long processes that are revealed by ZIO staining, by methylene blue and by scanning electron microscopy. Nerve fibers in the myenteric plexus are also GABA reactive (arrow). Fig. 9. Glial cells revealed by S-100 protein staining have small cell bodies (asterisks) and extend fine processes along the fine nerve strands of the tertiary component of the myenteric plexus (arrows). Calibrations: $20 \mu \mathrm{m}$. 


\section{Structure of the enteric nerve plexuses}

In the ZIO-stained preparations of the guinea-pig small intestine, nerve fibers were seen throughout the thickness of the gut wall. They were intermeshed with blood and lymphatic vessels and with the smooth muscular tissue and were prominent in the ganglionated plexuses. The general architecture of the enteric nerve plexuses seen in the present study coincides well with that previously reported by many authors, among them CAJAL $(1893,1911)$, STÖHR (1930), TAXi (1965), Kobayashi et al. (1986), FuRness and CosTA (1987).

\section{Periglandular and villous plexuses}

Both the ZIO and Golgi methods revealed a nerve network in the lamina propria mucosae in the villi and periglandular space of the guinea-pig small intestine. This was a three dimensional latticework embedded in the connective tissue beneath the epithelium and intermeshed with the vascular network, as previously described (DRASCH, 1881; CAJAL, 1911; STACH, 1977; KOBAYASHI et al., 1986).

It was not always possible to discriminate the two cellular elements in the nerve strands; namely, glial cells and neuronal processes. In particular, glial cells and nerve processes appeared continuous in Golgistained preparations (Fig. 5). With ZIO staining, neuronal processes were varicose in appearance. It was difficult to identify each neuronal process as a separate structure and also visualize all the internodal segments of each neuronal process.

Figs. 10-12. Staining for $Z I O$ at the level of the deep muscular plexus of the guinea-pig small intestine. Fig. 10 shows the deep muscular plexus stained with the conventional ZIO method; Figs. 11 and 12 show staining with ZIO to which a few drops of Tris $\mathrm{HCl}$ was added. Fig. 11 is from the boundary of a myectomy region and a normal area of intestine; fibroblast-like cells are indicated by arrows. Fig. 12 is from the denervated area, beneath the myectomy operation where the myenteric plexus was removed. With the usual ZIO method nerve fibers are well stained, but fibroblast-like cells are weakly stained or unstained. The fibroblast-like cells stained with ZIO plus tris $\mathrm{HCl}$ are generally aligned with the circular muscle cells (horizontal in these figures). They vary from having simple shapes with short processes (asterisk) to having several long branching processes (arrow). They generally lie close to nerve fiber bundles (Fig. 11). Calibrations: 20 $\mu \mathrm{m}$.
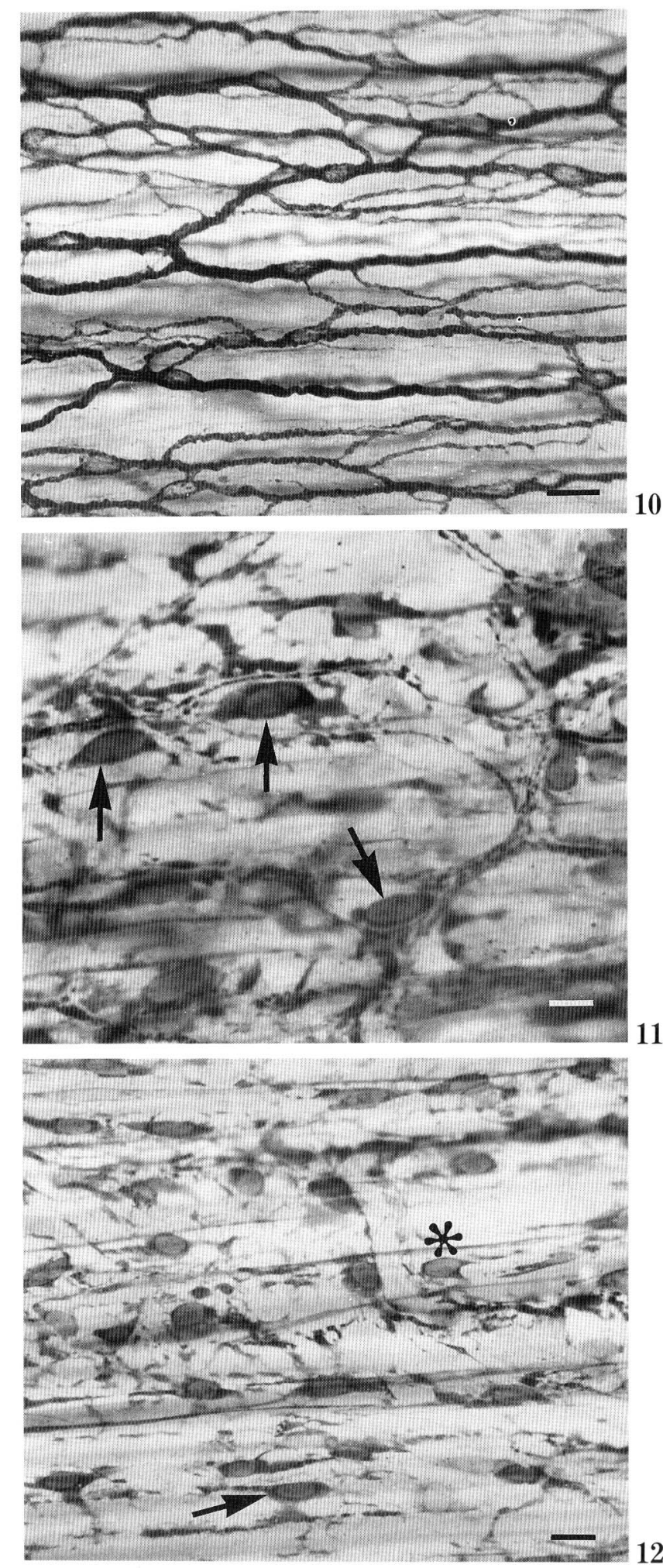
Varicose, thin twig-like processes which project from the tip of the thicker cytoplasmic process of the "interstitial cells" in CAJAL's drawings (Fig. 2 of CAJAL, 1889; Fig. 1 of JABONERO, 1965) were seen in the specimens prepared by the ZIO-method. These appear to be individual nerve fibers that reach the surface of the section and end where they have been cut. Based on our observations we conclude that what CAJAL $(1893,1911)$ identified as thin projections of the interstitial cells actually corresponds to a few nerve fiber processes ensheathed by a glial cell, which were stained together with the glial cell by the Golgi silver-impregnation method.

CAJAL $(1889,1893,1911)$ showed illustrations of the villous and periglandular plexuses in the guinea-pig small intestine (Fig. 2 of CAJAL, 1889; Fig. 3 of CAJAL, 1893; Fig. 568 and 579 of CAJAL, 1911; see Fig. 1). Most of these illustrations are not camera lucida drawings but diagrammatic representations made by combining many drawings. They appear to be based primarily on Golgi stained preparations. It seems likely that the small multipolar cells with numerous



Fig. 13. Perivascular plexus associated with a submucous arteriole, revealed by the ZIO staining method. Note the similarity to DoGIEL's drawing (Fig. 4). Arrows point to glial cells that lie along the nerve fiber bundles. In heavily stained preparations such as this the glial cells and nerve fiber bundles appear as if they are one structure. Calibration: $20 \mu \mathrm{m}$.

Fig. 14. Myenteric plexus layer of the guinea-pig small intestine viewed from the mucosal side. A Scanning electron micrograph of the myenteric plexus and $\mathbf{B}$ corresponding drawing. Networks of nerve strands associated with fibroblast-like cells $(F 1, F 2)$ are sandwiched between longitudinal muscle cells $(L M)$ and circular muscle cells. Two types of fibroblast-like cells can be seen: those with short tapering processes $(F 1)$ that are thought to be true fibroblasts, and those with long branching processes (F2). The latter fibroblast-like cells are probably identical with cells stained by ZIO, methylene blue and antibodies to GABA. They are most likely the cells that are generally identified as interstitial cells of Cajal at this site. $C$ blood capillary, $N$ nerve fiber bundle, $G$ glial cell enveloping part of a nerve bundle. Calibration $10 \mu \mathrm{m}$. 




\section{A}

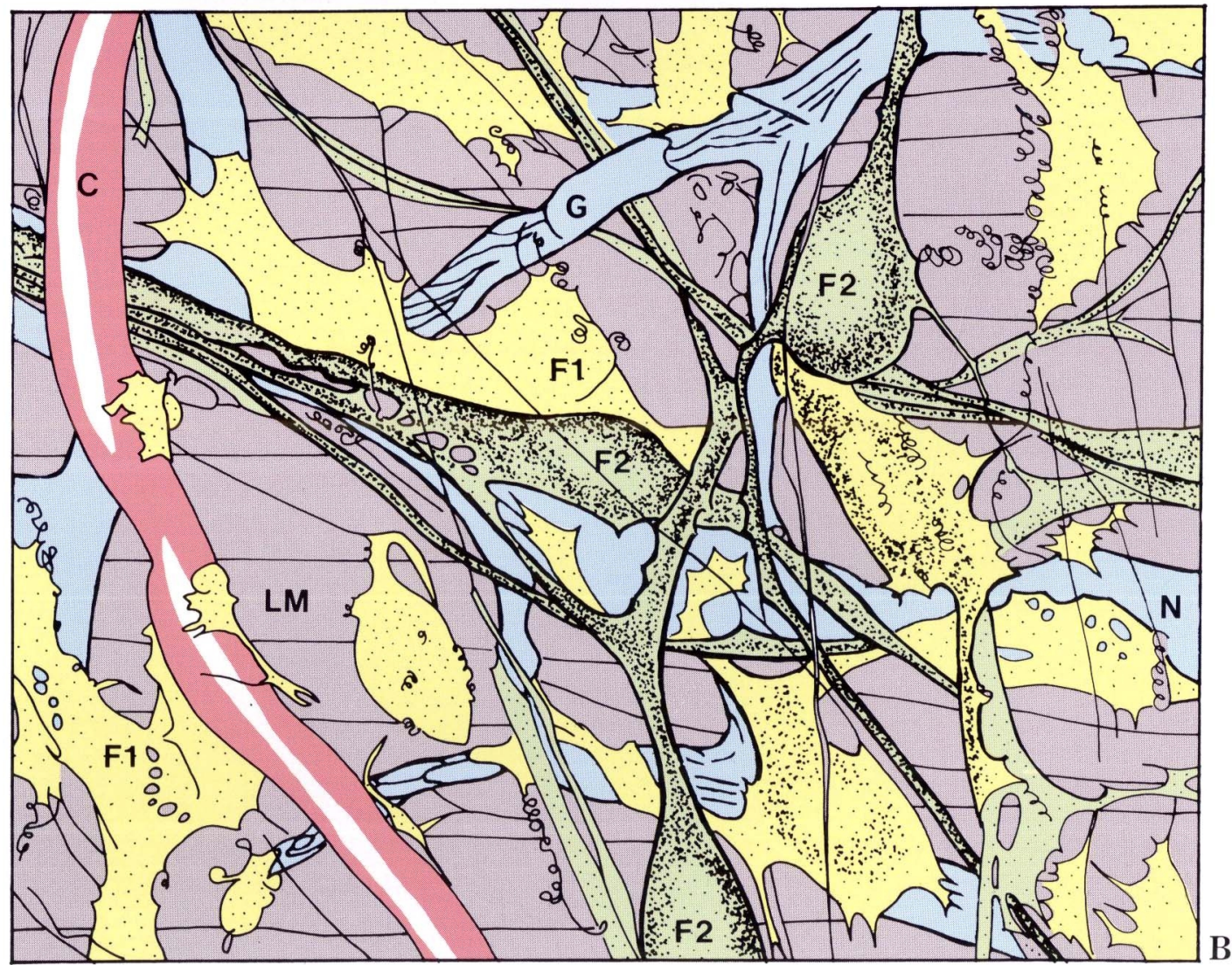

Fig. 14. Legend on the opposite page. 
short, frequently branching and varicose processes (interstitial cells according to CAJAL) are chimeras of glial cells and partly-stained varicose neuronal terminals. This interpretation is supported by examining the drawings and descripitions of CAJAL's contemporary RETZIUS (1892).

\section{Myenteric plexus}

As already reported by TAXI (1952, 1959, 1965), STACH (1972), RUMESSEN and THUNEBERG (1982) and Christensen et al. (1987) the neuronal elements of the myenteric plexus of the guinea-pig were wellstained by the ZIO-method. There was a less intense reaction of enteric glial cells. The structure of the myenteric ganglia and its primary and secondary strands were clearly demonstrated. The outline of the tertiary plexus was identical to that reported by KoBAYASHI et al. (1986). By the ZIO method both the glial and neuronal elements in the nerve fasciculi were demonstrated. With the method's conventional version, staining of nerve fibers was strong and that of glial cells was weak.

In addition to the nerve elements, fibroblast-like cells were stained by the ZIO method in the myenteric plexus layer, particularly after the addition of Tris $\mathrm{HCl}$ to the stain (Figs. 6, 7). These fibroblast-like cells had branching processes which sometimes approached each other. From their shapes and frequency of occurrence, these cells likely correspond to the interstitial cells of Cajal reported by TAXI (1965), STACH (1972), RUMESSEN and THUNEBERG (1982), CHRISTEN SEN et al. (1987) and MiKKELSEN et al. (1988).

The fibroblast-like cells form their own network. The meshes of this network are smaller than those of the tertiary component of the myenteric plexus. Strands of the fibroblast-like cell network are thinner and more variable in their spacing and branching patterns than the nerve fasciculi forming the tertiary plexus. The fibroblast-like cell network and the tertiary nerve fiber plexus overlie each other; at some points nerve fibers come close to fibroblast-like cells, but these close approaches appear incidental, as RICHARDISON (1958) observed.

Immunoreactivity for gamma-aminobutyric acid
(GABA) was seen in cells with morphologies and distributions identical to the fibroblast-like cells revealed by the ZIO technique (Fig. 8). This immunoreactivity was strongest after incubating specimens with GABA, but was also seen in preparations fixed without such preincubation. The network of fibroblast-like cells was different from the S-100 immunopositive cell network (Fig. 9). The outline of the tertiary plexus coincided with that of the S-100 protein immunopositive cells, but immunoreactive glial cell bodies were associated with only the larger nerve strands; they were not seen along the finest strands of this plexus (Fig. 9).

\section{Deep muscular plexus}

The deep muscular plexus has been examined by many authors using ZIO techniques (TAXI, 1965; RUMESSEN and THUNEBERG, 1982; WILSON et al., 1987). Results of the present examination of the small intestine of the normal guinea-pig were in accordance with those of previous investigations. Their morphology and distribution indicate that the fibroblast-like cells correspond to the interstitial cells of Cajal (ICCs-III) described by RUMESSEN and THUNEBERG (1982) and ThunEBERG (1982). The fibroblast-like cells vary greatly in number from specimen to specimen. We noticed that their visualization was improved by adding a few drops of Tris $\mathrm{HCl}$ buffer, by increasing the concentration of $\mathrm{OsO}_{4}$ in the $\mathrm{ZIO}$ solution or by prolonging treatment with the ZIO solution. When fibroblast-like cells occur in the deep muscular plexus, there are always ZIO-positive fibroblast-like cells with a similar morphology in the submucous layer. The distribution of neuronal terminals coincided with that of the S-100 protein immunopositive cells (enteroglial cells) reported by KOBAYASHI et al. (1986). The fibroblast-like cells of the deep muscular plexus were not seen with antibodies to GABA.

CAJAL (1911) illustrated interstitial cells of the deep muscular plexus (see Fig. 3). On one panel of this figure only neuronal processes are illustrated. It is clear that the pattern of the distribution of neuronal processes is in accordance with that of the S-100

Fig. 15. A tertiary nerve strand and fibroblast-like cells in the myenteric plexus layer of the guinea-pig small intestine. A Scanning electron micrograph showing a branching nerve strand consisting of glial cell processes (asterisks) and varicose nerve fibers (arrows); B corresponding drawing. Blunt cytoplasmic processes of F1 fibroblast-like cells are flat against the myenteric ganglion $(G)$. The long cytoplasmic processes of $\mathrm{F} 2$ fibroblastlike cells (arrowheads) have no varicosities, and hence can be distinguished from the nerve fibers. In this specimen, some connective tissue fibers of the myenteric plexus layer remain because they have not been completely digested by $\mathrm{NaOH}$ treatment. The $\mathrm{F} 1$ fibroblast-like cells have collagenous fibrils at their margins (small arrows). Calibration: $5 \mu \mathrm{m}$. 

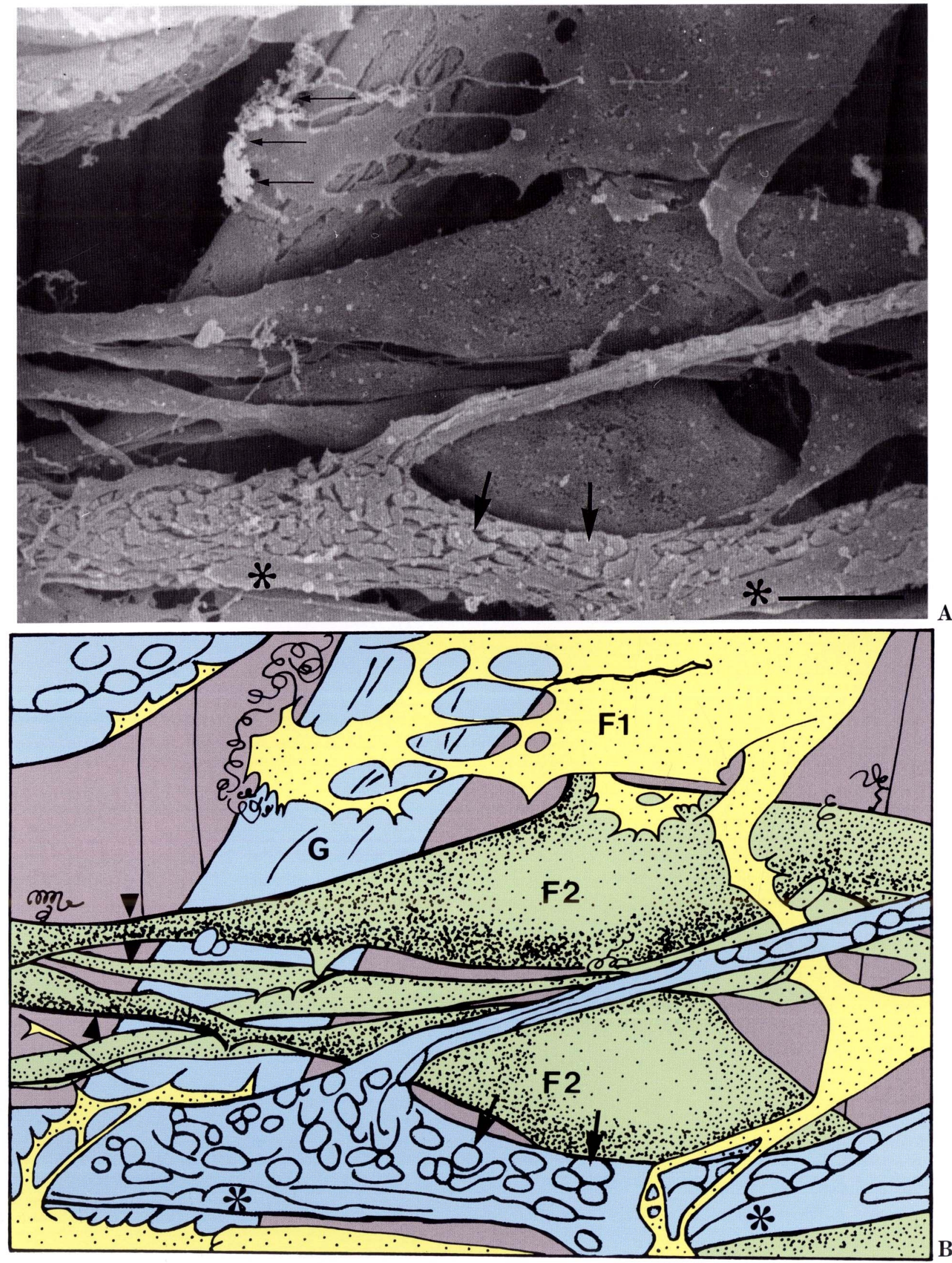

Fig. 15. Legend on the opposite page. 
protein immunopositive cells illustrated by KoBAYA . SHI et al. (1986) and with nerve fibers revealed by ZIO (Fig. 10). On the other hand, some of the interstitial cells illustrated by CAJAL (1911) (see upper panel of Fig. 3) may represent chimeras consisting of glial cells and fragments of neuronal processes which were simultaneously silver-impregnated by the Golgi method.

CAJAL (1911) reported that the cell bodies of the interstitial cells of the deep muscular plexus lay in small holes formed in the nerve fiber strands. Although ZIO reactive cell bodies sometimes occurred in this location, the majority lay adjacent to the nerve fiber bundles, as TAXI (1965) has already shown.

\section{Nature of the interstitial cells of Cajal as revealed by myectomy operations}

To further clarify the morphology of the ZIO positive fibroblast-like cells, we performed myectomy: the removal of a collar of longitudinal smooth muscle with attached myenteric plexus from the circumference of a segment of small intestine. The experimental procedures have been reported previously (see FuRnESS and COSTA, 1987). By this operation, a remarkable $99.3 \%$ of the neuronal processes in the underlying circular muscle layer are removed (WIL. SON et al., 1987). We were thus able to prepare specimens in which varicose neuronal processes were reduced or absent and fibroblast-like cells were selectively stained by the ZIO method (Figs. 11, 12). The morphology of the fibroblast-like cells fails to account for the long, branching, varicose processes illustrated by CAJAL (1911; see Fig. 3). Such long branching processes are rarely seen on the fibroblastlike cells either when they are observed amongst the nerve fibers in control specimens or separate from nerve fibers after operations.

Most fibroblast-like cells in the deep muscular plexus had tapering cytoplasmic processes which were short $(30 \mu \mathrm{m})$ and irregular in outline. However some fibroblast-like cells had more elaborate branching processes (Fig. 12), which could be traced for up to about four cell diameters from the cell body. The tip of the cytoplasmic process frequently abutted the cytoplasmic process of other fibroblast-like cells. There was a strong tendency for the longitudinal axes of the fibroblast-like cells to be arranged parallel to the long axes of the smooth muscle cells. The features of the fibroblast-like cells in the deep muscular plexus of the myectomy portion were different from those of both the S-100 protein immunopositive cells and the interstitial cells described by CAJAL (1911).

Our study of the deep muscular plexus of the myectomy portion of guinea-pig small intestine supports the idea that the interstitial cells of Cajal reported by previous authors using the ZIO method (TAXI, 1965; RUMESSEN and ThUNEBERG, 1982) are fibroblast-like cells. Although the interstitial cells described by CAJAL $(1893,1911)$ using the Golgi silver-impregnation method might be accounted for by the silver-impregnated amalgamation of an enteroglial cell and neuronal processes. TAXI (1952), also using Golgi impregnation, distinguished fibroblastlike cells with long branching processes that lie adjacent to nerve fiber bundles. He also identified spaces in the nerve fiber bundles where he deduced that the cell bodies of glial cells were located (Fig. 1 of TAXI, 1952). This location of glial cells conforms to the distribution that we have seen with S-100 protein localization.

\section{Perivascular nerve fiber bundles}

Perivascular nerves were best revealed in whole mounts of the submucosa stained for S100 or with ZIO. In association with the smaller arterioles of approximately $20-100 \mu \mathrm{m}$ diameter, we found a plexus of fine nerve fiber bundles with the same arrangement as DoGIEL (1899) described (see Fig. 4). In ZIO stained preparations, we observed varicose fibers and small fiber bundles as well as darkly stained structures where glial cells would be expected (Fig. 13). That glial cells were indeed located at these sites was confirmed by S100 immunohistochemistry. The glial cells appeared to be continuous with the small nerve fiber bundles in the light microscope.

Fig. 16. Deep muscular plexus layer of the guinea-pig small intestine. Scanning electron micrograph of the DMP and associated fibroblast-like cells (A) and corresponding drawing (B). Two types of fibroblast-like cells are distinguishable. The first type $(F 1)$ is characterized by a thin, blunt cytoplasmic process, and tends to lie flat on the nerve strands. The other fibroblast-like cell $(F 2)$ possesses long, branching cytoplasmic processes. They form an independent network which intermeshes with the nerve strand network. Arrows indicate thin smooth muscle cells characteristic of the innermost part of the circular muscle layer, $S M$ ordinary smooth muscle cells of the circular muscle layer beneath the deep muscular plexus (asterisks). Calibration: $10 \mu \mathrm{m}$. 



Fig. 16. Legend on the opposite page. 


\section{Scanning electron microscopy}

Scanning electron microscope observation affords visualization of all cells in a region, independent of the vagaries of more or less selective stains (Figs. 1417).

At the level of the myenteric plexus, nerve fiber processes and associated glial cells of its tertiary component were revealed. Two types of fibroblastlike cell were seen: the first type (F1) had short, sharply tapering processes and was flattened in the plane of the plexus; the second type (F2) extended long branching processes that were not varicose. The second cell type formed a pattern that was distinct from, but overlapped, the network formed by the tertiary plexus. The cells typically had triangular or spindle-shaped cell bodies and gave rise to 3-6 branching processes that lay in the plane of the myenteric plexus, giving the cells stellate appearances (Figs. 14, 15). The ends of the processes commonly formed flattened expansions that lay against other structures, such as smooth muscle cells or nerve fiber bundles.

In the deep muscular plexus, varicose fibers, glial cells and two types of fibroblast-like cells were seen against a background of smooth muscle (Figs. 16, 17). The glial cells had small somas and extended veillike processes that partly enveloped the bundles of nerve fibers (Fig. 14). The fibroblast-like cells lay close and generally parallel to the bundles of nerve fibers. They were oval cells with slightly dilated nuclear regions and tapering extensions. Some of the cells (F1 in Figs. 16, 17) had processes that were blunt ended, similar in appearance to the cells that were revealed by ZIO staining. However, there were other cells with long, branching, tapering processes. These latter cells generally resembled the structures described and drawn by TAXI (1952, 1965), who identified them as interstitial cells. The cells did not, however, show such profuse branching as was illustrated by CAJAL (1911). The cytoplasmic processes of the second type of fibroblast-like cell were obviously thicker than the intervaricose regions of nerve fibers (Figs. 15, 17), whereas the processes drawn by CAJAL (1911) (see Fig. 3) have about the same caliber as nerve fibers. It is quite feasible that ZIO stained the fibroblast-like cells with long processes without revealing these processes to their full extent.

The present scanning electron microscopic study easily differentiated between nerve fibers, long cytoplasmic processes of $\mathrm{F} 2$ fibroblast-like cells, and undigested collagenous and/or elastic fibrils. The nerve fibers were varicose and occurred in bundles associated with glial cells. The cytoplasmic processes of F2 fibroblast-like cells were remarkably thicker than the nerve fibers and were smooth and nonvaricose. Undigested collagenous and/or elastic fibrils were very thin and had a rough surface. They often originated from the fringes of the fibroblasts.

Within the myenteric plexus layer, the fibroblastlike cells that we identified by scanning electron microscopy appeared identical to those reported by KomURo (1982) and BALUK and GABELla (1987) using this technique.

\section{DISCUSSION}

In the present work we have compared cells described as interstitial cells by CAJAL with cell types revealed in those regions where he made his identifications. We have focused attention on the cells of the deep muscular plexus and of the plane between the longitudinal and circular muscle layers of the muscularis externa.

At the level of the deep muscular plexus, scanning electron microscopy revealed two types of fibroblastlike cells: a flattened cell with blunt processes (F1), and second cell type (F2) with long branching processes. Transmission microscopy also revealed two cells, one of which appears to be a true fibroblast, with abundant rough endoplasmic reticulum, and the other with long branching processes and numerous intracellular caveoli (RUMESSEN et al., 1982; ENDO et al., 1987). This second cell type has been identified, by workers who described it, with interstitial cells. It seems certain that the F1 fibroblast-like cell is a true fibroblast, and that the F2 cell is the same cell as is usually identified as an interstitial cell of Cajal. Nevertheless, it is not clear which cells were de-

Fig. 17. Nerve network and fibroblast-like cells in the deep muscular plexus layer of the guinea-pig small intestine. Scanning electron micrograph (A) and corresponding drawing (B) showing fibroblast-like cells (F2) with long branching cytoplasmic processes (arrows), lying against the nerve fiber bundles $(N)$ of the deep muscular plexus; smooth muscle cells $(S M)$ in the circular muscle layer are also present. The morphology of the fibroblast-like cells $(F 2)$ is quite distinctive. Calibration: $10 \mu \mathrm{m}$. 


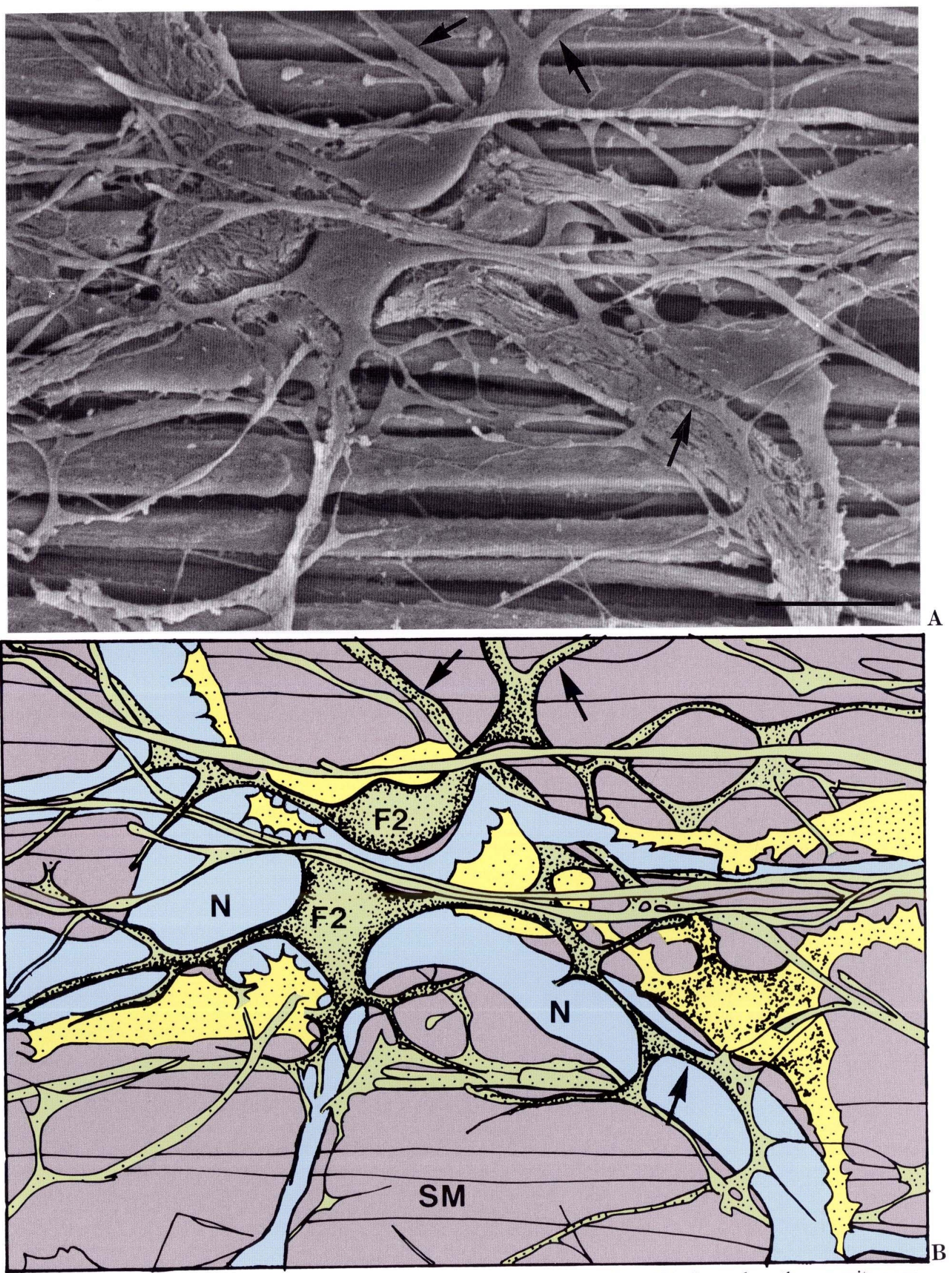

Fig. 17. Legend on the opposite page. 
scribed by CAJAL. His drawings do not suggest glial cells, although he places the somas of the interstitial cells in "holes" in the nerve strands where cell bodies of glial cells are encountered. On the other hand, SEM does reveal F2 fibroblast-like cells, with appearances akin to the cells drawn by CAJAL. The majority of these cells, however, do not have such extensive branching processes as CAJAL described. The long processes of $\mathrm{F} 2$ fibroblast-like cells differ in appearance from neurites in the deep muscular plexus in being generally smooth and of greater calibre. CAJAL, however, drew neurites and processes of interstitial cells in similar fashion. Cells stained by the ZIO method are also less elaborate than CAJAL's drawings indicate.

Taking all these into consideration we conclude the following: CAJAL may have seen composite cells in which the cell body of a glial or fibroblast-like cell appeared continuous with closely related and partially stained nerve fibers. Such chimeras seem more likely to occur in Golgi-stained preparations. On the other hand, he may have seen some of the F2 fibroblast-like cells that have long processes with either Golgi or methylene blue staining and extrapolated from these that, if adequately stained, all such cells would look like those in his drawing.

In the myenteric plexus, CAJAL's drawings look like the network of enteric glial cells, as far as cellular shape is concerned. However, he drew a far greater density of cells in the tertiary plexus region than is revealed by immunohistochemical localization of the glial cell marker, S-100 protein. Moreover, CAJAL did not draw interstitial cells in the myenteric ganglia or the principal connecting strands of the plexus, where enteric glial cells are very common (but, see Fig. 19 of DoGIEL, 1899). We therefore conclude, as have other authors (RICHARDSON, 1958; TAXI, 1959), that CAJAL did not describe glial cells between the outer muscle layers as interstitial cells. On the other hand, F2 fibroblast-like cells occur with a frequency similar to CAJAL's cells and, like the cells in his drawings, have small somas and branching processes. These fibroblast-like cells are of similar appearance, whether revealed by methylene blue staining (MIKKELSON et al., 1988), by ZIO staining, GABA immunoreactivity, or scanning electron microscopy. However, these cells have rather broader processes which are more irregular in outline than CAJAL showed in his drawings. These cells, called ICC-I by THUNEBERG, are most probably the cells that CAJAL saw in his methylene blue stained preparations.

In the mucosa, scanning electron microscopy reveals cells that resemble conventional fibroblasts (ENDO and KoBAyashi, 1987). Cells with long processes resembling those in the deep muscular plexus and at the level of the myenteric plexus have not been found in the mucosa. CAJAL's descriptions and drawings would indicate that he based his identification of mucosal interstitial cells on Golgi preparations. Having examined such preparations, we are convinced that, what CAJAL described as interstitial cells in the mucosa are composite structures consisting of glial cells and nerve fiber bundles (see Fig. 5). In the scanning electron microscope, when the dilated parts of small axon bundles where glial cells lie are combined with the fiber bundles themselves, they can appear remarkably like small multipolar cells (see Fig. 3 of ENDO and KoBAyASHI, 1987; Fig. 7 of USHIKI and IDE, 1988).

In conclusion, CAJAL's descriptions and drawings have proved inadequate for a definitive identification of the structures that he called interstitial cells in the mucosa, the deep muscular plexus, and between the outer muscle coats of the small intestine. It has already been concluded that none of these structures are neurons (THUNEBERG, 1982). At the level of the deep muscular plexus there are spindle-shaped fibroblast-like cells that, following THUNEBERG's terminology, are referred to as type III interstitial cells (ICC-III), and at the level of the myenteric plexus there are stellate fibroblast-like cells that are identified as ICC.I. Both cell types are readily identified by scanning electron microscopy.

A great deal of speculation has developed concerning the functions of the interstitial cells (BOTAR, 1966; Thuneberg, 1982; Furness and Costa, 1987; Ber. EZIN et al., 1988). In this review we have kept away from these speculations, in the belief that they will best be settled by first clearly defining which structures are being discussed, and next by trying to ascertain of their physiological properties, perhaps recording from them with intracellular microelectrodes.

Acknowledgments. We should like to thank Michiko SuzuKI and Dianne TRUSSELl for their excellent assistance with the experiments, and Michele HofFmann for her care and patience in typing the drafts and final manuscript. We should also like to thank Dr. B. E. MALEY for providing the anti-GABA antiserum. 


\section{REFERENCES}

Baluk, P. and G. Gabella: Scanning electron microscopy of the muscle coat of the guinea-pig small intes tine. Cell Tiss. Res. 250: 551-561 (1987).

Berezin, I., J. D. Huizinga and E. E. Daniel: Interstitial cells of Cajal in the canine colon: a special communication network at the inner border of the circular muscle. J. Comp. Neurol. 273: 42-51 (1988).

BoTAR, J.: The autonomic nervous system. Akademiai Kiado, Budapest, 1966.

CaJal, S. R. Y: Sobre la red nerviosa ganglionar de las vellosidades intestinales. Gaceta Med. Catal. 12: 614616 (1889).

-: Sur les ganglions et plexus nerveux de l'intestin. C. R. Soc. Biol. Paris 5: 217-223 (1893).

-: Histologie du système nerveux de l'homme et des vertébrés. Maloine, Paris, 1911.

Champy, C.: Granules et substances reduisant l'iodure d' osmium. J. Anat. Physiol. Paris 49: 323-343 (1913).

Christensen, J., G. A. RICK and D. J. Soll: Intramural nerves and interstitial cells revealed by the ChampyMaillet stain in the oppossum esophagus. J. Autonom. Nerv. Syst. 19: 137-151 (1987).

Dogiel, A. S.: Über den Bau der Ganglien in den Geflechten des Darmes und der Gallenblase des Menschen und der Säugethiere. Arch. Anat. Physiol. (Leipzig) Anat. Abt.: 130-158 (1899).

Drasch, O.: Beiträge zur Kenntniss des feineren Baues des Dünndarms, insbesondere über die Nerven desselben. Sitzber. Akad. Wiss. Wien 82: 168-198 (1881).

Endo, Y., T. Endo and S. Kobayashi: Electron microscopic study on S-100 protein immunoreactive cells in the guinea-pig duodenum, with special reference to the interstitial cells of Cajal. Neurosci. Lett. 79: 272-276 (1987).

ENDo, Y. and S. KobaYASHI: A scanning electron microscope study on the autonomic groundplexus in the lamina propria mucosae of the guinea-pig small intestine. Arch. Histol. Jap. 50: 243-250 (1987).

Furness, J. B. and M. Costa: Projections of intestinal neurons showing immunoreactivity for vasoactive intestinal polypeptide are consistent with these neurons being the enteric inhibitory neurons. Neurosci. Lett. 15: 199-204 (1979).

chill Livingstone, Edinburgh, 1987.

Furness, J. B., M. Costa, A. Rokaeus, T. J. McDonald and B. Brooks: Galanin-immunoreactive neurons in the guinea-pig small intestine: their projections and relationships to other neurons. Cell Tiss. Res. 250: 607615 (1987).

Furness, J. B., J. C. Bornstein and D. C. Trussell: Shapes of nerve cells in the myenteric plexus of the guinea-pig small intestine revealed by the intracellular injection of dye. Cell Tiss. Res. 254: 561-571 (1988).
Furness, J. B., D. C. Trussell, S. Pompolo, J. C. Bornstein, B. E. Maley and J. Storm-Mathisen: Shapes and projections of neurons with immunoreactivity for gamma-aminobutyric acid in the guineapig small intestine. Cell Tiss. Res. (1989, in press).

JABOnero, V.: Mikrophotographische Darstellung der wirklichen interstitiellen Zellen von Cajal. Cajalsche Originalpräparate 1889-1894. J. Neural Transmit. 27: 496-510 (1965).

Kobayashi, S., M. Suzuki, T. Endo, S. Tsuji and E. E. DANIEL: Framework of the enteric nerve plexuses: an immunocytochemical study in the guinea pig jejunum using an antiserum to S-100 protein. Arch. Histol. Jap. 49: 159-188 (1986).

Komuro, T.: The interstitial cells in the colon of the rabbit: scanning and transmission electron microscopy. Cell Tiss. Res. 222: 41-51 (1982).

LAWRENTJEW, B. I.: Über die nervöse Natur und das Vorkommen der sogenannten interstitiellen Zellen (Cajal, Dogiel) in der glatten Muskulatur. Proc. Koninkl. Nederl. Akad. Wet. 28: 977-983 (1925).

- Über die Verbreitung der nervösen Elemente (einschliesslich der "interstitiellen Zellen" Cajals) in der glatten Muskulatur, ihre Endigungsweise in den glatten Muskelzellen. Z. Mikrosk. Anat. Forsch. 6: 467-488 (1926).

MaILlet, M.: Modifications de la technique de Champy au tetroxyde d'osmium-iodure du potassium. Resultats de son application a l'etude des fibres nerveuses. C. R. Séanc. Soc. Biol. 53: 939-940 (1959).

MALEY, B. and B. Newton: Immunohistochemistry of $\gamma$-aminobutyric acid in the cat nucleus tractus solitarius. Brain. Res. 330: 364-368 (1985).

Mannen, H.: A dendro-cyto-myeloarchitectonic atlas of the cat's brain. Iwanami Shoten, Tokyo, 1988.

Mikkelsen, H. B., L. Thuneberg and I. H. Wittrup: Selective double staining of interstitial cells of Cajal and macrophage-like cells in small intestine by an improved supravital methylene blue technique combined with FITC-dextran uptake. Anat. Embryol. 178: 191195 (1988).

Murakami, T.: A revised tannin-osmium method for non-coated scanning electron microscope specimens. Arch. Histol. Jap. 36: 189-193 (1974).

Ottersen, O. P., J. Storm-Mathisen, S. Madsen, S. Skumlia and J. Stromhaug: Evaluation of the immunocytochemical method for amino acids. Med. Biol. 64: 147-158 (1986).

Pellegrino De Iraldi, A.: Significance of the Maillet method (ZIO) for cytochemical studies of subcellular structures. Experientia 33: 1-10 (1977).

Retzius, G.: Über die Anfänge der Drüsengänge und die Nervenendigungen in den Speicheldrüsen des Mundes. In: G. RETZIUS: Biologische Untersuchungen, III. Samson and Wallin, Stockholm, 1892 (p. 60-64 and plate 22).

Richardson, K. C.: Electronmicroscopic observations on Auerbach's plexus in the rabbit, with special reference to the problem of smooth muscle innervation. Amer. J. Anat. 103: 99-136 (1958). 
Rumessen, J. J. and L. Thuneberg: Plexus muscularis profundus and associated interstitial cells. 1. Light microscopical studies of mouse small intestine. Anat. Rec. 203: 115-127 (1982).

Rumessen, J. J., L. Thuneberg and H. B. Mikkelsen: Plexus muscularis profundus and associated interstitial cells. II. Ultrastructural studies of mouse small intestine. Anat. Rec. 203: 129-146 (1982'.

STACH, W.: Der Plexus entericus extremus des Dickdarmes und seine Beziehungen zu den interstitiellen Zellen (Cajal). Z. Mikrosk. -Anat. Forsch. 85: 245-272 (1972).

: Darmwandneurone und Zottenplexus. Verh. Anat. Ges. 71: 861-865 (1977).

SтöнR, P.: Mikroskopische Studien zur Innervation des Magen-Darmkanales. Z. Zellforsch. 12: 66-154 (1930).

Takahashi-Iwanaga, H. and T. Fujita: Application of an $\mathrm{NaOH}$ maceration method to a scanning electron microscopic observation of Ito cells in the rat liver. Arch. Histol. Jap. 49: 349-357 (1986).

TAXI, J.: Cellules de Schwann et "cellules interstitielles de Cajal" au niveau des plexus nerveux de la musculeuse intestinale dü cobaye: retour aux définitions. Arch. Anat. Microsc. Morphol. Exp. 41: 281-304 (1952).

: Sur la structure des travées du plexus d'Auerbach: confrontation des données fournies par le microscope ordinaire et par le microscope électronique. Ann. Sci. Nat. Zool. 1: 571-594 (1959).

: Contribution a l'etude des connexions des neurones moteurs du système nerveux autonome. Ann. Sci. Nat. Zool. 7: 413-674 (1965).
ThuneberG, L.: Interstitial cells of Cajal: intestinal pacemaker cells? Adv. Anat. Embryol. Cell Biol. 71:1130 (1982).

UshiKI, T. and C. IDE: Autonomic nerve networks in the rat exocrine pancreas as revealed by scanning and transmission electron microcopy. Arch. Histol. Cytol. 51: 71-81 (1988).

Wilson, A. J., I. J. Llewellyn-Smith, J. B. Furness and M. Costa: The source of the nerve fibers forming the deep muscular and circular muscle plexuses in the small intestine of the guinea-pig. Cell Tiss. Res. 247: 497-504 (1987).
Prof. Shigeru KobaYashi

Department of Anatomy

Yamanashi Medical College

Tamaho, Yamanashi

409-38 Japan

小林 繁

409-38 山梨県中巨摩郡玉穂町

山梨医科大学

解剖学教室 